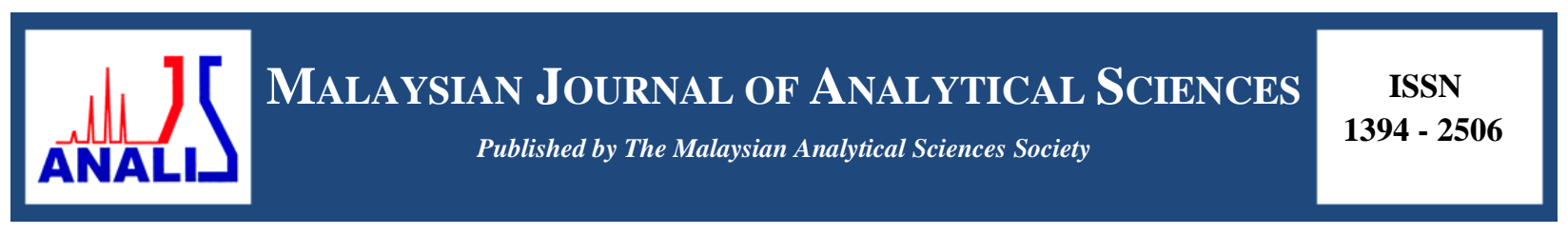

\title{
SEASONAL VARIATION AND ECOLOGICAL RISK ASSESSMENT OF HEAVY METAL CONTAMINATION IN SURFACE WATERS OF THE GANGES RIVER (NORTHWESTERN BANGLADESH)
}

\author{
(Variasi Bermusim dan Penilaian Risiko Ekologi Terhadap Pencemaran Logam Berat di \\ Permukaan Air Sungai Ganges (Barat Utara Bangladesh))
}

\author{
Md. Ayenuddin Haque ${ }^{1}$, Md. Abu Sayed Jewel ${ }^{1}$, Jakia Hasan ${ }^{2}$, Md. Mazharul Islam ${ }^{3}$, Sharif Ahmed $^{3}$, Lubna Alam $^{4} *$ \\ ${ }^{I}$ Department of Fisheries, Faculty of Agriculture, \\ University of Rajshahi, Rajshahi-6205, Bangladesh \\ ${ }^{2}$ Bangladesh Fisheries Research Institute, \\ Marine Fisheries \& Technology Station, Cox's Bazar-4700, Bangladesh \\ ${ }^{3}$ Marine Fisheries Academy, \\ Fish Harbour, Isanagore, Chittagong-4000, Bangladesh \\ ${ }^{4}$ Institute for Environment and Development (LESTARI), \\ Universiti Kebangsaan Malaysia, 43600 UKM Bangi, Selangor, Malaysia \\ *Corresponding author: lubna762120@gmail.com
}

Received: 20 April 2018; Accepted: 11 February 2019

\begin{abstract}
The present work is evaluating the seasonal variation in metal pollution and the ecological risk indices of surface water of the Ganges River (Northwestern Bangladesh). Concentrations of $\mathrm{Cr}, \mathrm{Pb}, \mathrm{Ni}, \mathrm{Cd}, \mathrm{As}, \mathrm{Cu}$ and $\mathrm{Zn}$ in surface water samples were determined by Flame Atomic Absorption Spectrophotometry. The level of heavy metals did not exceed the permissible limits of drinking water according to Department of Environment (DOE), Bangladesh and World Health Organization (WHO). Only Cr and $\mathrm{Cd}$ concentrations exceeded the permissible limits for aquatic life standards of the United States Environmental Protection Agency (USEPA) and Canadian Council of Ministers of the Environment (CCME). The heavy metal pollution index (HPI) showed that the seasonal contamination level followed the order: summer (136.13 (DoE), 220.72 (WHO) and 163.95 (USEPA, CCME)) > winter (57.38 (DoE), 91.36 (WHO) and 72.81 (USEPA, CCME)) > monsoon (16.49 (DoE), 25.36 (WHO) and 19.44 (USEPA, CCME)). Additionally, the HPI value crossed the critical index value (100) for drinking and aquatic life standard during summer season. The metal index (MI) value showed that the water was moderately (DoE), strongly (WHO) and seriously affected (USEPA, CCME) by heavy metals during summer season (3.15, 4.79 and 9.99 according to DoE, WHO and USEPA, CCME, respectively). While the ecology of the river is presently at low risk, this study suggests taking necessary measures to prevent the present pollution rate of contaminants from rising in the future.
\end{abstract}

Keywords: heavy metals, surface water, ecological risk indices, metal index

\section{Abstrak}

Kajian ini menilai variasi bermusim pencemaran logam dan indeks risiko ekologi bagi permukaan air di Sungai Ganges (Barat utara Bangladesh). Kepekatan $\mathrm{Cr}, \mathrm{Pb}, \mathrm{Ni}, \mathrm{Cd}, \mathrm{As}, \mathrm{Cu}$ dan $\mathrm{Zn}$ dalam sampel permukaan air ditentukan oleh spektofotometri nyalaan serapan atom. Berdasarkan Jabatan Alam Sekitar (DoE) Bangladesh dan Pertubuhan Kesihatan Sedunia (WHO), tahap logam berat tidak melebihi paras yang dibenarkan bagi air minum. Hanya kepekatan $\mathrm{Cr}$ dan $\mathrm{Cd}$ melebihi had yang dibenarkan untuk piawaian akuatik badan Agensi Perlindungan Alam Sekitar Amerika Syarikat (USEPA) dan Majlis Menteri-Menteri Alam Sekitar Kanada (CCME). Indeks pencemaran logam berat (HPI) menunjukkan bahawa tahap pencemaran bermusim mengikuti susunan: musim panas (136.13 (DoE), 220.72 (WHO) dan 163.95 (USEPA, CCME)) > musim sejuk (57.38 (DoE), 91.36 (WHO) 


\section{Haque et al: SEASONAL VARIATION AND ECOLOGICAL RISK ASSESSMENT OF HEAVY METAL CONTAMINATION IN SURFACE WATERS OF THE GANGES RIVER (NORTHWESTERN BANGLADESH)}

(USEPA, CCME)) > monsun (16.49 (DoE), 25.36 (WHO) dan 19.44 (USEPA, CCME)). Di samping itu, nilai HPI mencapai nilai indeks kritikal (100) untuk piawai air minuman dan hidupan akuatik semasa musim panas. Nilai indeks logam (MI) menunjukkan bahawa airnya sederhana (DoE), kuat (WHO) dan serius terjejas (USEPA, CCME) oleh logam berat pada musim panas $(3.15,4.79$ dan 9.99 berdasarkan DOE, WHO dan USEPA). Walaupun ekologi sungai pada masa ini berisiko rendah, kajian ini bercadang untuk mengambil langkah-langkah yang perlu untuk mencegah kadar pencemaran semasa daripada meningkat pada masa akan datang.

Kata kunci: logam-logam berat, permukaan air, indeks risiko ekologi, indeks logam

\section{Introduction}

Environmental pollution is a worldwide concern and heavy metals are among the most impactful pollutants. Heavy metal contamination in aquatic ecosystems is a major concern due to the toxicity, persistence, non-biodegradable character and abundance of these metals in the environment, as well as their accumulation in aquatic habitats [1, 2]. Natural processes and activities related to urbanization and agriculture are basically the main contributors to heavy metal pollution in aquatic habitats [3]. While heavy metals in water exist only in trace concentrations, they are toxic to the human body. Therefore, water quality is a pressing issue in many countries. Currently, the vulnerability of water to contaminants from natural and anthropogenic sources has become a common global problem [4].

The Ganges River, which flows alongside Rajshahi city, is popularly known as Padma River in Bangladesh. It is very important for its multidimensional use as a fishery and for domestic (bathing and washing clothes) and recreational activities. However, in recent years, the continuous increase in demographic, the urbanized expansion and the increased weight for inhabitants in the city makes the aquatic ecosystem of this river the ultimate recipient of pollutants from various sources. These sources include industrial and municipal wastewater, urban surface water runoff, runoff from agricultural fields and other natural resources. Furthermore, with the construction of Farakka Barrage on the Ganges River in West Bengal of India, the flow of the river is decreasing daily. Therefore, water flow is comparatively slower today than during previous dry seasons. Slow water flow sometimes extends the standing time of pollutants; therefore, the pollutants easily subside into the water and sediment. Apart from these pollutants, during the dry season, agricultural activities are performed in waterless areas and fertilizer, pesticides and other wastes from these agricultural processes are typically discharged into the river.

Considering their biological and environmental threat, it is important to assess several heavy metals in the surface water of this river. Fully understanding the current heavy metal profile of this part of Ganges River is crucial for ecological safety. However, there is no such research that focuses on heavy metals in the surface water of the Ganges River in the Rajshahi region. Therefore, the current study was conducted to evaluate the concentration of heavy metals during different seasons in the surface water and the comprehensive assessment of ecological risk due to their contamination.

\section{Study area}

\section{Materials and Methods}

The study locations selected for the present study were T-dam (Site-1), Padma garden (Site-2), I-dam (Site-3) and Talaimari point (Site-4). All of these sites were situated between $24^{\circ} 21^{\prime} 42.41^{\prime \prime} \mathrm{N}$ and $24^{\circ} 21^{\prime \prime} 29.30^{\prime \prime} \mathrm{N}$ and $88^{\circ} 34^{\prime} 31.18^{\prime \prime}$ E to $88^{\circ} 37^{\prime} 30.55^{\prime \prime}$ E (Figure 1) along the coast of Rajshahi city. Rajshahi falls within the western dry zone, which is one of the seven climatic zones that divides Bangladesh. As Rajshahi city does not possess any sewage system, the surface run-off essentially acts as a sewer, taking the overflow from septic tanks, domestic waste, wastes from commercial units, markets and small industries and ultimately discharging them all into the Ganges River. 


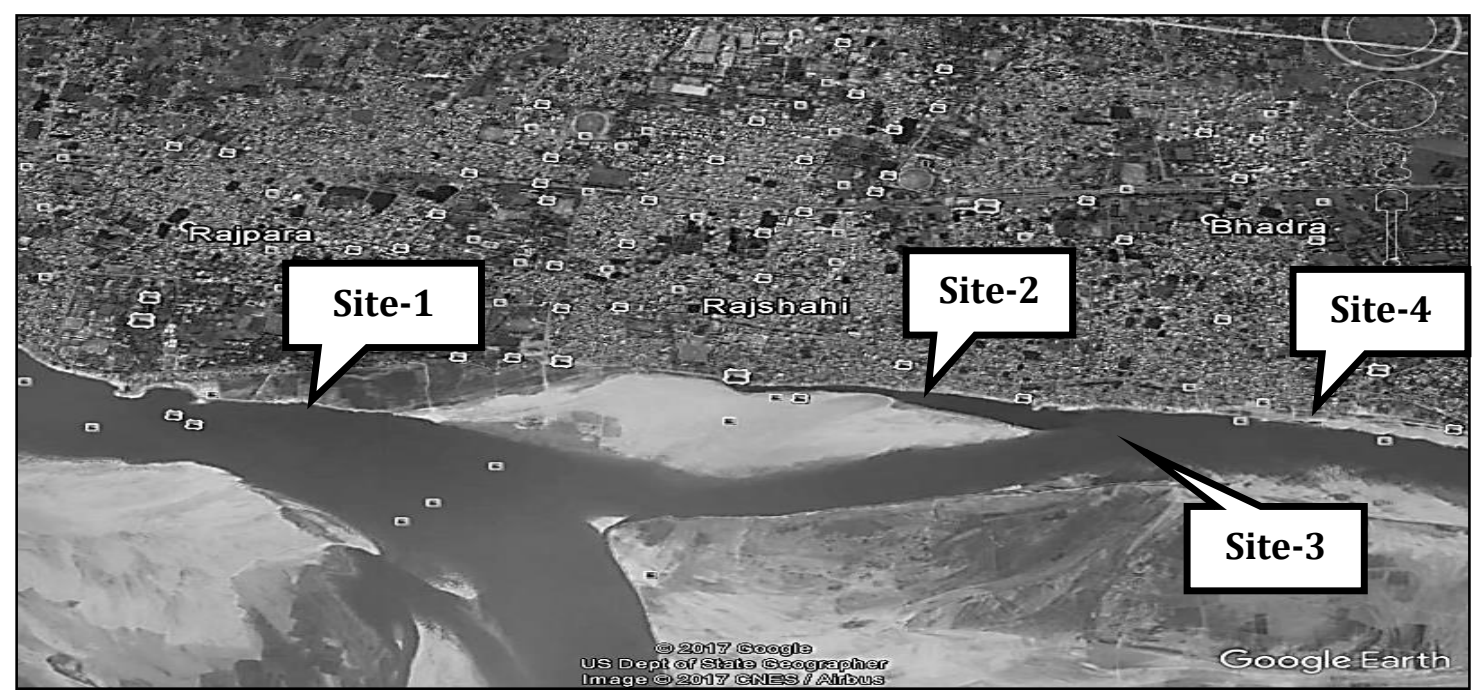

Figure 1. Location of the study area. Modified from Google Earth-2017

\section{Sample collection}

A total of 12 water samples were collected from four study sites during the three study seasons (summer, monsoon and winter). Samples were collected from $10 \mathrm{~cm}$ below the water surface and stored in $100 \mathrm{~mL}$ polyethylene bottles at each site. Each bottle was washed more than three times in order to guarantee the monitoring accuracy. The sampling bottles were previously soaked and rinsed in $10 \% \mathrm{HNO}_{3}$ overnight. The collected water samples were acidified with concentrated $\mathrm{HNO}_{3}$ at $\mathrm{pH}<2$ to avoid precipitation of heavy metals. Samples were kept on ice and brought to the laboratory, where they were stored in a refrigerator with a temperature below $4{ }^{\circ} \mathrm{C}$ to prevent evaporation until analysis [5].

\section{Digestion and analysis of heavy metals}

Wet digestion of the samples was conducted in freshly prepared aqua regia $\left(1: 3 \mathrm{HNO}_{3}: \mathrm{HCl}\right)$ on a block digester to obtain $100 \mathrm{~mL}$ of aliquot. The heavy metal $(\mathrm{Cr}, \mathrm{Pb}, \mathrm{Ni}, \mathrm{Cd}, \mathrm{Mn}, \mathrm{As}, \mathrm{Cu}$ and $\mathrm{Zn})$ concentrations in the water samples were measured with the Flame Atomic Absorption Spectrometer (Shimadzu, AA-6800) in the central lab of University of Rajshahi, Bangladesh.

\section{Pollution evaluation indices: Heavy metal pollution index}

The heavy metal pollution index (HPI) is a rating system that provides the aggregate influence of individual heavy metals on the total water quality. The rating system is an arbitrary value between 0 and 1 . Its selection depends on the importance of individual quality considerations or it can be defined as inversely proportional to the standard permissible value $(\mathrm{Si})$ for each parameter [6,7]. The HPI is determined by using the formula equation 1 below [8]:

$$
\text { HPI }=\frac{W_{i} \times Q_{i}}{1}
$$

where $W \mathrm{i}$ and $Q i$ are the unit weightage and sub-index of the $\mathrm{i}^{\text {th }}$ parameter, respectively; $W i$ is calculated by the weightage of $i^{\text {th }}$ parameter and is given as equation 2 below:

$$
W i=\frac{K}{S i}
$$

where $W i$ is the unit weightage and $S i$ is the recommended standard for the $\mathrm{i}^{\text {th }}$ parameter, while $k$ is the constant of proportionality. Individual quality rating, $Q i$, is given by the expression in equation 3 below: 


\section{Haque et al: SEASONAL VARIATION AND ECOLOGICAL RISK ASSESSMENT OF HEAVY METAL CONTAMINATION IN SURFACE WATERS OF THE GANGES RIVER (NORTHWESTERN BANGLADESH)}

$$
Q i=\frac{100 \times V i}{S i}
$$

where $Q i$ is the sub index of $\mathrm{i}^{\text {th }}$ parameter, $V i$ is the monitored value of the $\mathrm{i}^{\text {th }}$ parameter and $S i$ is the standard or permissible limit for the $\mathrm{i}^{\text {th }}$ parameter. The critical pollution index value is 100 [9]. For the present study, the $S i$ value was obtained from the World Health Organization (WHO) standard [10, 11].

\section{Metal index}

According to Tamasi and Cini [12], the metal index (MI) was calculated using the following formula (equation 4):

$$
\mathrm{MI}=\sum_{i=1}^{n} \frac{C_{i}}{(M A C)_{i}}
$$

where $C i$ is the concentration of each element and $M A C$ is the maximum allowable concentration. An MI value $>1$ is a threshold of warning [13]. Classification of MI according to literature studies [14, 15] shown in Table 1.

\begin{tabular}{|c|c|c|c|c|}
\hline \multirow{2}{*}{ Metal Index } & \multicolumn{4}{|c|}{ Potential Ecological Risk Indices } \\
\hline & $C_{f}^{i}$ & $C d$ & $E_{r}^{i}$ & PERI \\
\hline \multicolumn{5}{|l|}{$<0.3$, Very pure } \\
\hline \multicolumn{5}{|l|}{$0.3-1.0$, Pure } \\
\hline $1.0-2.0$, Slightly & $<1$, non & $<8$, low & $<40$, low & $<150$, low \\
\hline affected & contaminated & $\geq 8<16$, moderate & $\geq 40<80$, moderate & $\geq 150<300$ \\
\hline $2.0-4.0$, Moderately & $\geq 1<2$, light & $\geq 16<32$, relatively & $\geq 80<100$, strong & moderate \\
\hline affected & $\geq 2,<3$, moderate & high & $\geq 320$, extremely & $\geq 300<600$, strong \\
\hline $\begin{array}{c}4.0-6.0, \text { Strongly } \\
\text { affected }\end{array}$ & $\geq 3$, heavy & $\geq 32$, very high & high & $\geq 600$, very strong \\
\hline$>6.0$, Seriously affected & & & & \\
\hline
\end{tabular}

Table 1. Evaluation standards for metal index (MI) and potential ecological risk indices (PERI)

\section{Potential ecological risk factor and risk index}

The potential ecological risk index method was proposed by Hakanson [16] from a sedimentology perspective to assess the characteristics and environmental behaviour of heavy metal contaminants. The specific formulas are as follows:

The single contamination coefficient (equation 5):

$$
C_{f}^{i}=\frac{C_{s l}^{i}}{C_{n}^{i}}
$$

where $C_{f}^{i}$ is the contamination coefficient of a particular heavy metal, $C_{s l}^{i}$ is the measured data of heavy metals, and $C_{n}^{i}$ is the reference value. In the present study, the reference value of heavy metals was taken from freshwater quality criteria for protection of aquatic life of United States Environmental Protection Agency (USEPA) [17] and the Canadian Council of Ministers of the Environment (CCME) [18]. The comprehensive contamination measure $(C d)$ as shown in equation 6:

$$
\mathrm{C}_{\mathrm{d}}=\sum C_{f}^{i}
$$

The potential ecological risk index (PERI) was calculated using equation 7: 


$$
\mathrm{PERI}=\sum E_{r}^{i}
$$

where PERI is risk index; $E_{r}^{i}$ is the potential ecological risk index for the pollution of a single heavy metal and can be calculated using equation 8 :

$$
E_{r}^{i}=C_{f}^{i} \times T_{f}^{i}
$$

where $T_{f}^{i}$ and $C_{f}^{i}$ are the response coefficient and contamination coefficient of single heavy metal, respectively. The value of $T_{f}^{i}$ of each metal was taken from literature studies $[16,19]$. The corresponding degrees of contamination and the evaluation standards for the levels of potential ecological risk are based on past results from relevant studies $[20,21]$ as tabulate in Table 1.

\section{Statistical analysis}

The calculation of risk indices was conducted in Microsoft Excel (Microsoft Office 2010). The correlation analysis was performed by SPSS software (version 20).

\section{Distribution of metals in different seasons and sites}

\section{Results and Discussion}

The results of heavy metal concentrations in surface water is shown in Table 2. The comparison of present findings with other national and international rivers is shown Table 3, where the present findings is compared with those from past research [22-28]. The average concentration of studied metals followed the decreasing order: $\mathrm{Cr}>\mathrm{Zn}>$ $\mathrm{Cu}>\mathrm{Pb}>\mathrm{Cd}>\mathrm{Ni}>\mathrm{As}$. The same distribution pattern of studied heavy metals was also shown in both summer and winter seasons. Therefore, $\mathrm{Cr}$ was the most abundant metal among metals. Its high value during the dry season notably may be due to high evaporation of surface water followed by elevated temperatures [29]. The higher concentration of $\mathrm{Cr}$ during the dry months was also reported in the Buriganga River, Bangladesh [30], in Cooum River, India [31] and in the Taizi River, China [32]. However, irregular patterns of these metals were observed during monsoon season (Table 2).

Table 2. Heavy metal concentrations (mg/L) at different seasons and sites of the Ganges River during the study period

\begin{tabular}{lcccccccc}
\hline Season & Sites & $\mathbf{C r}$ & $\mathbf{P b}$ & $\mathbf{N i}$ & $\mathbf{C d}$ & $\mathbf{A s}$ & $\mathbf{C u}$ & $\mathbf{Z n}$ \\
\hline \multirow{3}{*}{ Summer } & Site-1 & 0.018 & 0.009 & 0.005 & 0.006 & 0.002 & 0.012 & 0.011 \\
& Site-2 & 0.102 & 0.022 & 0.006 & 0.014 & 0.003 & 0.045 & 0.110 \\
& Site-3 & 0.092 & 0.023 & 0.005 & 0.009 & 0.006 & 0.011 & 0.027 \\
& Site-4 & 0.010 & 0.005 & 0.001 & 0.004 & 0.002 & 0.006 & 0.007 \\
\hline Summer & & $0.056 \pm$ & $0.015 \pm$ & $0.004 \pm$ & $0.008 \pm$ & $0.003 \pm$ & $0.019 \pm$ & $0.039 \pm$ \\
(Average \pm SD) & & 0.048 & 0.009 & 0.002 & 0.004 & 0.002 & 0.018 & 0.048 \\
\hline \multirow{3}{*}{ Monsoon } & Site-1 & 0.002 & 0.002 & ND & 0.001 & ND & ND & ND \\
& Site-2 & 0.006 & 0.001 & ND & 0.001 & ND & 0.003 & ND \\
& Site-3 & 0.005 & 0.003 & ND & ND & ND & 0.001 & ND \\
& Site-4 & 0.003 & 0.001 & ND & ND & ND & ND & 0.002 \\
\hline Monsoon & & $0.004 \pm$ & $0.002 \pm$ & ND & $0.001 \pm$ & & $0.002 \pm$ & $0.002 \pm$ \\
(Average \pm SD) & & 0.002 & 0.001 & ND & 0.001 & & 0.001 & 0.000 \\
\hline
\end{tabular}




\section{Haque et al: SEASONAL VARIATION AND ECOLOGICAL RISK ASSESSMENT OF HEAVY METAL CONTAMINATION IN SURFACE WATERS OF THE GANGES RIVER (NORTHWESTERN BANGLADESH)}

Table 2(cont'd). Heavy metal concentrations ( $\mathrm{mg} / \mathrm{L})$ at different seasons and sites of the Ganges River during the study period

\begin{tabular}{|c|c|c|c|c|c|c|c|c|}
\hline Season & Sites & $\mathrm{Cr}$ & $\mathbf{P b}$ & $\mathbf{N i}$ & Cd & As & $\mathbf{C u}$ & $\mathbf{Z n}$ \\
\hline \multirow{4}{*}{ Winter } & Site-1 & 0.020 & 0.005 & 0.001 & 0.001 & 0.001 & 0.003 & 0.040 \\
\hline & Site-2 & 0.100 & 0.025 & 0.003 & 0.004 & 0.004 & 0.022 & 0.078 \\
\hline & Site-3 & 0.087 & 0.014 & 0.006 & 0.006 & 0.003 & 0.016 & 0.019 \\
\hline & Site-4 & 0.008 & 0.002 & 0.001 & 0.002 & 0.001 & 0.002 & 0.010 \\
\hline \multirow{2}{*}{$\begin{array}{l}\text { Winter } \\
\text { (Average } \pm \text { SD) }\end{array}$} & & $0.054 \pm$ & $0.012 \pm$ & $0.003 \pm$ & $0.003 \pm$ & $0.002 \pm$ & $0.011 \pm$ & $0.037 \pm$ \\
\hline & & 0.046 & 0.010 & 0.002 & 0.002 & 0.002 & 0.010 & 0.030 \\
\hline \multirow{2}{*}{\multicolumn{2}{|c|}{$\begin{array}{l}\text { Total } \\
\text { Average } \pm \text { SD }\end{array}$}} & $0.038 \pm$ & $0.009 \pm$ & $0.004 \pm$ & $0.005 \pm$ & $0.003 \pm$ & $0.012 \pm$ & $0.030 \pm$ \\
\hline & & 0.043 & 0.009 & 0.002 & 0.004 & 0.002 & 0.013 & 0.035 \\
\hline \multicolumn{2}{|l|}{${ }^{\mathrm{a}} \mathrm{DWSB}$} & 0.050 & 0.050 & 0.100 & 0.005 & 0.050 & 1.000 & 5.000 \\
\hline \multicolumn{2}{|l|}{${ }^{\mathrm{b}} \mathrm{WHO}$} & 0.050 & 0.070 & 0.010 & 0.003 & 0.010 & 2.000 & 0.500 \\
\hline \multicolumn{2}{|l|}{$\begin{array}{l}{ }^{\mathrm{c}} \text { USEPA, } \\
{ }^{\mathrm{d}} \mathrm{CCME}\end{array}$} & 0.016 & 0.065 & 0.470 & 0.002 & 0.340 & 0.013 & 0.050 \\
\hline
\end{tabular}

Note: SD, standard deviation, ND = Not detected.

${ }^{a}$ Drinking water standard for Bangladesh proposed through ECR (Department of Environment, Government of the People's Republic of Bangladesh, [40, 41].

${ }^{b}$ Drinking water standard of WHO $[10,11]$

Aquatic life standard of water proposed by ${ }^{\mathrm{c}}$ USEPA [17] and ${ }^{\mathrm{d}} \mathrm{CCME}$ [18].

The highest concentrations of $\mathrm{Cr}, \mathrm{Cd}, \mathrm{Cu}$ and $\mathrm{Zn}$ were recorded at Site-2 during summer season; at the same site, $\mathrm{Pb}$ showed its maxima during winter season. On the other hand, As showed its highest value at Site-3 during summer season. One possible reason for the higher value during the dry season may be due to the low water level and flow in the river; these entities were not substantial enough to dilute the disposal of sewage sludge and industrial effluents from septic tanks and metal industries. Therefore, during these low flow conditions, the accumulation of these metal concentration increases in river water. Such an effect was also previously noted by Yao et al. [33] and Dey et al. [34]. As such, the lower concentrations of heavy metals during the monsoon may be due to the dilution effect of pollutant $[35,36]$. These temporal variations in the metal concentrations were generally consistent with seasonal variations in metal concentrations that have been reported in other rivers [37, 38, 39]. The possible reasons for higher concentration of metals at Site-2 followed by Site-3 might be due to presence of large drains at those sites that regularly empty their contents without treatment into the river. A similar observation was also made by [39], in the Nil river, where untreated discharged sewage and poultry waste were responsible for the elevated metal levels in the water.

During the study period, the average concentrations of all the metals were below the drinking water guidelines of both Department of Environment (DoE) [40, 41] and WHO [10, 11]. However, only the average concentration of $\mathrm{Cr}$ $(0.038 \mathrm{mg} / \mathrm{L})$ and $\mathrm{Cd}(0.005)$ exceeded the aquatic life guidelines of USEPA [17] and CCME [18]. The average concentration of the studied metals in the Padma River was also higher than the previous findings in the same river [22] as tabulate in Table 3.

The Pearson's correlation (PC) matrix for the analysed heavy metals is in Table 4. The metals showed a significant positive correlation with each other except for $\mathrm{Cu}-\mathrm{As}, \mathrm{Zn}-\mathrm{Ni}$ and $\mathrm{Zn}$-As. A significant correlation among most of the metals suggested similar sources of input (human or natural), similar levels of contamination and a mutual dependence in the river system for these metals $[42,43]$. On the other hand, the negative associations in the matrix indicate that the increase in one of the parameters results in the decrease of the other and vice versa. Those variables with negative associations suggest that those metals do not have identical sources of pollution, as their sources of pollution differ [44]. 
Table 3. Comparison of heavy metal concentrations $(\mathrm{mg} / \mathrm{L})$ in water of Ganges River with national and international rivers

\begin{tabular}{lcccccccl}
\hline Rivers & $\mathbf{C r}$ & $\mathbf{P b}$ & $\mathbf{N i}$ & $\mathbf{C d}$ & $\mathbf{A s}$ & $\mathbf{C u}$ & $\mathbf{Z n}$ & References \\
\hline Ganges River, Bangladesh & 0.0378 & 0.0093 & 0.0035 & 0.0048 & 0.0028 & 0.0121 & 0.0304 & Present study \\
Padma River, Bangladesh & 0.0030 & 0.0015 & 0.0081 & 0.0020 & 0.0015 & 0.0200 & 0.0073 & {$[22]$} \\
Meghna River, Bangladesh & 0.0346 & - & - & 0.0030 & - & - & 0.0364 & {$[23]$} \\
Buriganga River, Bangladesh & 0.1140 & 0.1119 & 0.1500 & 0.0590 & - & - & 0.3320 & {$[24]$} \\
Dhaleshwari River, Bangladesh & 0.4413 & 0.0500 & 0.0072 & 0.0065 & - & 0.1547 & - & {$[25]$} \\
Ganga river, India & - & 0.1200 & 0.1400 & 0.0500 & - & 0.0100 & 0.0600 & {$[26]$} \\
Mahrut River, Iraq & 0.4961 & 0.2180 & 0.0860 & 0.0080 & - & - & 0.0028 & {$[27]$} \\
Yangtz River, China & 0.0210 & 0.0550 & - & 0.0047 & - & 0.0110 & 0.0094 & {$[28]$} \\
\hline
\end{tabular}

Table 4. Correlation among the heavy metals in water of Ganges River, Bangladesh

\begin{tabular}{llllllll}
\hline & $\mathbf{C r}$ & $\mathbf{P b}$ & $\mathbf{N i}$ & $\mathbf{C d}$ & $\mathbf{A s}$ & $\mathbf{C u}$ & $\mathbf{Z n}$ \\
\hline $\mathrm{Cr}$ & 1 & & & & & & \\
$\mathrm{~Pb}$ & $0.964^{* *}$ & 1 & & & & & \\
$\mathrm{Ni}$ & $0.817^{* *}$ & $0.794^{* *}$ & 1 & & & & \\
$\mathrm{Cd}$ & $0.781^{* *}$ & $0.786^{* *}$ & $0.879^{* *}$ & 1 & & & \\
$\mathrm{As}$ & $0.861^{* *}$ & $0.910^{* *}$ & $0.779^{* *}$ & $0.737^{* *}$ & 1 & & \\
$\mathrm{Cu}$ & $0.812^{* *}$ & $0.793^{* *}$ & $0.770^{* *}$ & $0.884^{* *}$ & 0.574 & 1 & \\
$\mathrm{Zn}$ & $0.777^{* *}$ & $0.781^{* *}$ & 0.568 & $0.707^{*}$ & 0.534 & $0.901^{* *}$ & 1 \\
\hline
\end{tabular}

** Correlation is significant at the 0.01 level (2-tailed)

* Correlation $\left(\mathrm{R}^{2}\right)$ is significant at the 0.05 level (2-tailed)

\section{Pollution evaluation indices: Heavy metal pollution index}

The heavy metal pollution index (HPI) was in order the of: summer > winter > monsoon during the study period (Figure 2). The HPI value of summer season was far above the critical index value (100) for drinking water and aquatic life standards. This finding may be attributed to the disposal of domestic and municipal sewage and their lower dilution rate. During dry seasons, the river basin was available for agricultural activities, which also contributes to the increasing level of HPI during this season. Similarly, a previous study found agricultural activities as a major source of heavy meal in a tropical mountainous river in India [45]. Therefore, the HPI index suggested that better agricultural management practices need to be implemented during dry season for maintaining ecological integrity and protecting the lotic system from further degradation. However, the low computed value of HPI during monsoon season might be a result of the dilution of pollutants as was previously reported [6]. 


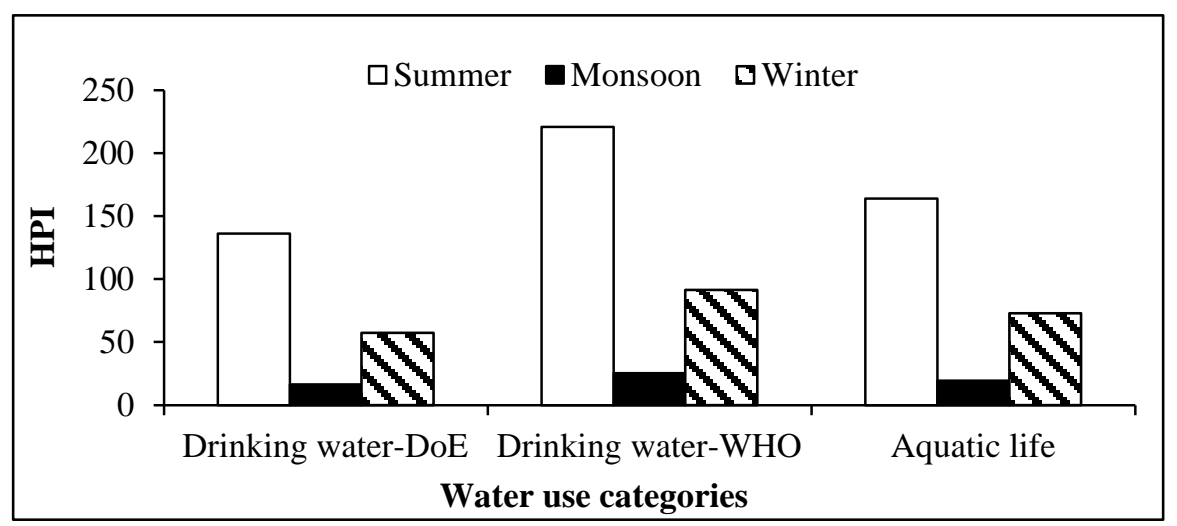

Figure 2. Heavy metal pollution index (HPI) in the Ganges River water according to the guideline levels of drinking and aquatic life water

\section{Metal index}

The metal index (MI), which was used for a better understanding of pollution status of Ganges River water during different seasons, is shown in Figure 3. The MI showed great variability among the seasons. According to the index value (9.99), during the summer season, the river water was seriously affected with heavy metals that can endanger the existence of the aquatic life. However, during the monsoon season, the dilution effect of flood water resulted in the reduction of the concentrations of the metals and thus the value of the MI. The effect of dilution on metal concentration have also been evident by Giri and Singh [46].

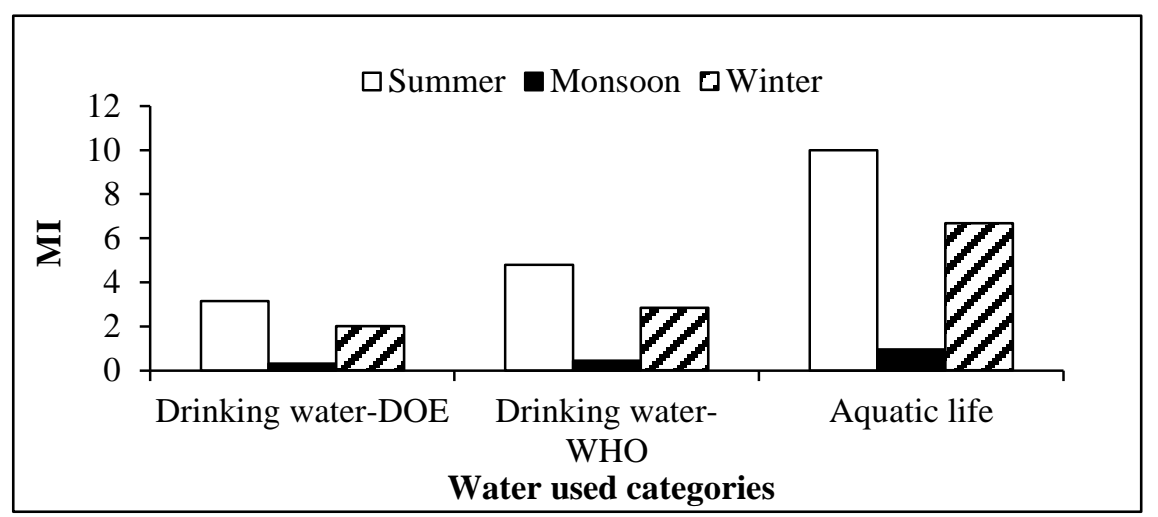

Figure 3. Metal index (MI) of surface water in the Ganges River according to the guideline levels of drinking and aquatic life water

\section{Potential ecological risk index}

The contamination factors of a single regulator $\left(C_{f}^{i}\right)$ and the degree of contamination $\left(\sum C_{f}^{i}\right)$ are shown in Table 5 . The contamination factors of the seven heavy metals in this study decreased in the following order: $\mathrm{Cr}>\mathrm{Cd}>\mathrm{Cu}>$ $\mathrm{Zn}>\mathrm{Pb}>\mathrm{Ni}$ and As. Therefore, according to the contamination factor, the surface water of Ganges River was moderately contaminated with $\mathrm{Cr}$ and lightly contaminated with $\mathrm{Cd}$ and $\mathrm{Cu}$. The surface water was notcontaminated with $\mathrm{Pb}, \mathrm{Ni}$, As and $\mathrm{Zn}$. The degree of contamination indicates the moderate contamination of water during summer and low contamination during other two seasons. 
Table 5. Contamination factor $\left(C_{f}^{i}\right)$ and degree of contamination $(C d)$ of heavy metals of surface water in Ganges River, Bangladesh

\begin{tabular}{|c|c|c|c|c|c|c|c|c|c|}
\hline \multirow{2}{*}{ Seasons } & \multicolumn{7}{|c|}{ Contamination factor $\left(C_{f}^{i}\right)$} & \multirow{2}{*}{$=\sum C_{f}^{i}$} & \multirow{2}{*}{ Level } \\
\hline & $\mathrm{Cr}$ & $\mathbf{P b}$ & $\mathbf{N i}$ & Cd & As & $\mathrm{Cu}$ & $\mathbf{Z n}$ & & \\
\hline Summer & 3.50 & 0.23 & 0.01 & 4.00 & 0.01 & 1.46 & 0.78 & 9.99 & Moderate \\
\hline Monsoon & 0.25 & 0.03 & 0.00 & 0.50 & 0.00 & 0.15 & 0.04 & 0.97 & Low \\
\hline Winter & 3.38 & 0.18 & 0.01 & 1.50 & 0.01 & 0.85 & 0.74 & 6.66 & Low \\
\hline Average & 2.38 & 0.15 & 0.01 & 2.00 & 0.01 & 0.82 & 0.52 & 5.87 & Low \\
\hline $\begin{array}{l}\text { Contamination } \\
\text { level }\end{array}$ & Moderate & $\begin{array}{l}\text { Non- } \\
\text { Contaminaed }\end{array}$ & $\begin{array}{l}\text { Non- } \\
\text { contaminated }\end{array}$ & Light & $\begin{array}{l}\text { Non- } \\
\text { contaminated }\end{array}$ & Light & Non- & taminated & \\
\hline
\end{tabular}

The ecological risk factor $\left(E_{r}^{i}\right)$ and potential ecological risk index (PERI) are shown in Table 6 . The severity of the potential ecological risk for individual metals $\left(E_{r}^{i}\right)$ decreased in the order of $\mathrm{Cd}>\mathrm{Cr}>\mathrm{Cu}>\mathrm{Pb}>\mathrm{Zn}>\mathrm{As}>\mathrm{Ni}$. $\mathrm{Cd}$ is the most important metal and its risk factor indicates that the Ganges River was moderately contamination with this metal. Other heavy metals $(\mathrm{Cr}, \mathrm{Pb}, \mathrm{Ni}, \mathrm{As}, \mathrm{Cu}$ and $\mathrm{Zn})$ showed low potential for ecological risk. A similar result also reported $\mathrm{Cd}$ as the most important of the metal pollutants, in terms of the risks it posed [33]. The PERI that accounted for the contamination caused by studied seven metals indicates the low potential ecological risk of the surface water of this river during the summer, monsoon and winter seasons. However, the level of risk that was evident during the study period should be reduced. Open municipal drain, household garbage and industrial pollutants should be checked with high priority so that they cannot enter into the river water. Furthermore, the local government should establish a treatment plant for these city wastes to protect the environment of the river.

Table 6. Ecological risk factor and Potential Ecological Risk Index (PERI) of heavy metals of surface water in Ganges River, Bangladesh

\begin{tabular}{|c|c|c|c|c|c|c|c|c|c|}
\hline \multirow{2}{*}{ Seasons } & \multicolumn{7}{|c|}{ Ecological Risk Factor $\left(E_{r}^{i}\right)$} & \multirow{2}{*}{$\begin{array}{l}P E R I \\
=\sum E_{r}^{i}\end{array}$} & \multirow{2}{*}{$\begin{array}{l}\text { Contamination } \\
\text { Level }\end{array}$} \\
\hline & $\mathrm{Cr}$ & $\mathbf{P b}$ & $\mathbf{N i}$ & Cd & As & $\mathrm{Cu}$ & $\mathbf{Z n}$ & & \\
\hline Summer & 7.00 & 1.15 & 0.04 & 120.00 & 0.09 & 7.31 & 0.78 & 136.37 & Low \\
\hline Monsoon & 0.50 & 0.15 & ND & 15.00 & ND & 0.77 & 0.04 & 16.46 & Low \\
\hline Winter & 6.75 & 0.92 & 0.03 & 45.00 & 0.06 & 4.23 & 0.74 & 57.73 & Low \\
\hline Average & 4.75 & 0.74 & 0.04 & 60.00 & 0.08 & 4.10 & 0.52 & 70.19 & Low \\
\hline $\begin{array}{l}\text { Contamination } \\
\text { Level }\end{array}$ & Low & Low & Low & Moderate & Low & Low & Low & & \\
\hline
\end{tabular}

\section{Conclusion}

The risk assessment on heavy metals using risk indices (HPI and MI) indicates that currently the analysed water sources from the Ganges River were unfit for drinking water and aquatic life standards. The risk was potentially high during the summer and winter seasons. Although the overall potential risk index showed a low contamination level, the increasing level of environmental pollution might make the ecosystem of the Ganges River (Northwestern Bangladesh) more alarming. Therefore, the present study recommends strict management actions to be taken in order to protect the ecological sustainability of this important river.

\section{Acknowledgement}

The authors are grateful to the Ministry of Higher Education Malaysia for providing funding (Grant no. TRGS/1/2015/UKM/02/5/2) and the Ministry of Science and Technology and the Government of the People's 


\section{Haque et al: SEASONAL VARIATION AND ECOLOGICAL RISK ASSESSMENT OF HEAVY METAL CONTAMINATION IN SURFACE WATERS OF THE GANGES RIVER (NORTHWESTERN BANGLADESH)}

Republic of Bangladesh for providing the National Science and Technology Fellowship (Grant no. 39.00.0000.012.20.004.16-439) for this research work.

\section{References}

1. Bastami, K. D., Bagheri, H., Kheirabadi, V., Zaferani, G. G., Teymori, M. B., Hamzehpoor, A., Soltani, F. and Ganji, S. (2014). Distribution and ecological risk assessment of heavy metals in surface sediments along southeast coast of the Caspian Sea. Marine Pollution Bulletin, 81(1): $262-267$.

2. Fu, J., Zhao, C., Luo, Y., Liu, C., Kyzas, G. Z., Luo, Y., Zhao, D. and Zhu, H. (2014). Heavy metals in surface sediments of the Jialu River, China: Their relations to environmental factors. Journal of Hazardous Materials, 270: $102-109$.

3. Krishna, A. K., Satyanarayanan, M. and Govil, P. K. (2009). Assessment of heavy metal pollution in water using multivariate statistical techniques in an industrial area: A case study from Patancheru, Medak District, Andhra Pradesh, India. Journal of Hazardous Materials, 167(1): 366 - 373.

4. Mohamed, A. A. J., Ibrahim, A. R., Lee, H. L., Hanna, M., Mohamed, M., Fadilah, T. and Nur, A. R. (2016). Assessment of groundwater quality parameters in northern region of Zanzibar Island. Journal of Chemical Engineering and Bioanalytical Chemistry, 1: $1-8$.

5. Sehgal, M., Garg, A., Suresh, R. and Dagar, P. (2012). Heavy metal contamination in the Delhi segment of Yamuna basin. Environmental Monitoring and Assessment, 184: 1181 - 1196.

6. Reza, R. and Singh, G. (2010). Heavy metal contamination and its indexing approach for river water. International Journal of Environmental Science and Technology, 7: 785 - 792.

7. Prasad, B. and Sangita, K. (2008). Heavy metal pollution index of ground water of an abandoned open cast mine filled with fly ash: A case study. Mine Water and the Environment, 27: 265 - 267.

8. Ojekunle, O. Z., Ojekunle, O. V., Adeyemi, A. A., Taiwo, A. G., Sangowusi, O. R., Taiwo, A. M. and Adekitan, A. A. (2016). Evaluation of surface water quality indices and ecological risk assessment for heavy metals in scrap yard neighbourhood. Springer Plus, 5: 560.1

9. Prasad, B. and Kumari, S. (2008). Heavy metal pollution index of ground water of an abandoned open cast mine filled with fly ash: A case study. Mine Water and the Environment, 27(4): 265 - 267.

10. World Health Organization (2011). Guidelines for drinking-water quality. Word Health Organisation, Geneva.

11. World Health Organization (2008). Guidelines for drinking-water quality: incorporating $1^{\text {st }}$ and $2^{\text {nd }}$ addendum: Vol. 1 - recommendations, $3^{\text {rd }}$ edition. World Health Organisation, Geneva.

12. Tamasi, G. and Cini, R. (2004). Heavy metals in drinking waters from Mount Amiata. Possible risks from arsenic for public health in the province of Siena. Science of the Total Environment, 327: $41-51$.

13. Bakan, G., Bokeozkoc, H., Tulek, S. and Cuce, H. (2010). Integrated environmental quality assessment of Kizilırmak River and its coastal environment. Turkish Journal of Fisheries and Aquatic Sciences, $10: 453$ 462.

14. Lyulko, I., Ambalova, T. and Vasiljeva, T. (2001). To integrated water quality assessment in Latvia. In: MTM (Monitoring Tailor-Made) III, Proceedings of International Workshop on Information for Sustainable Water Management, Netherlands, pp. $449-452$.

15. Caerio, S., Costa, M. H., Ramos T. B., Fernandes, F., Silveira, N., Coimbra, A., Mederios, G. and Painho, M. (2005). Assessing heavy metal contamination in Sado Estuary sediment: An index analysis approach. Ecological Indicators, 5: 151 - 169.

16. Hakanson, L. (1980). An ecological risk index for aquatic pollution control a sedimentological approaches. Water Research, 14(8): 975 - 1001.

17. United States Environmental Protection Agency (USEPA). Partition coefficient of metals in surface water, soil and waste, Office of the Research and Development, EPA/600/R-05/074, 2005, 2006.

18. Canadian Council of Ministers of the Environment (1999). For the protection of aquatic life. In: Canadian environmental quality guidelines. Canadian Council of Ministers of the Environment, Winnipeg.

19. Xu, Z. Q., Ni, S. J. and Tho, X. G. (2008). Calculation of heavy metals toxicity coefficient in the evaluation of potential ecological risk index. Environmental Science \& Technology, 31: 112 - 115.

20. Dong, J., Bian, Z. and Wang, H. (2007). Comparison of heavy metal contents between different reclaimed soils and the control soil. Journal of China University of Mining \& Technology, 36(4): 531 - 536.

21. Jiao, B., Xu, G., Li, D., Luo, J. and Yang, K. (2012). Hazards of heavy metals in coal. Disaster Advances, 5(4): $1812-1818$. 
22. Jolly, Y. N., Akter, J. S., Kabir, A. I. and Akbar, S. (2013). Trace elements contamination in the river padma. Bangladesh Journal of Physics, 13: 95 - 102.

23. Hassan, M., Mirza, A. T. M., Rahman, T., Saha, B. and Kamal, A. K. I. (2015). Status of heavy metals in water and sediment of the Meghna River, Bangladesh. American Journal of Environmental Sciences, 11: 427 - 439.

24. Bhuiyan, M. A. H., Dampare, S. B., Islam, M. A. and Suzuki, S. (2015). Source apportionment and pollution evaluation of heavy metals in water and sediments of Buriganga River, Bangladesh, using multivariate analysis and pollution evaluation indices. Environmental Monitoring and Assessment, 187: 4075.

25. Ahmed, M. K., Ahmed, S., Rahman, S., Haque, M. R. and Islam, M. M. (2008). Heavy metals concentration in water, sediment and their bioaccumulation in some freshwater fishes and mussel in Dhaleshwari River, Bangladesh. Terrestrial and Aquatic Environment Toxicology, 3(1): 33 - 41.

26. Aktar, M. W., Paramasivam, M., Ganguly, M., Purkait, S. and Sengupta, D. (2010). Assessment and occurrence of various heavy metals in surface water of Ganga river around Kolkata: a study for toxicity and ecological impact. Environmental Monitoring and Assessment, 160(1-4): 207 - 213.

27. Al-Obaidy, A. H. M. J., Al-Mashhady, A. A. M., Awad, E. S. and Kadhem, A. J. (2014). Heavy metals pollution in surface water of Mahrut River, Diyala, Iraq. International Journal of Advanced Research, 2 (10): $1039-1044$.

28. Liu, H. and Li, W. (2011). Dissolved trace elements and heavy metals from the shallow lakes in the middle and lower reaches of the Yangtze River region, China. Environmental Earth Sciences, 62(7): 1503.

29. Majhi, A. and Biswal, S. K. (2016). Application of HPI (heavy metal pollution index) and correlation coefficient for the assessment of ground water quality near ash ponds of thermal power plants. International Journal of Science Engineering and Advance Technology, 4(8): 395 - 405.

30. Ahmad, M. K., Islam, S., Rahman, S., Haque, M. R. and Islam, M. M. (2010). Heavy metals in water, sediment and some fishes of Buriganga River, Bangladesh. International Journal of Environmental Research, 4(2): 321 332.

31. Kalaivani, T. R. and Dheenadayalan, M. S. (2013). Seasonal fluctuation of heavy metal pollution in surface water. International Research Journal of Environment Science, 2(12): 66 - 73.

32. Song, X., Hu, X., He, M., Liang, R., Li, X. and Sun, W. (2013). Spatial distribution and seasonal variations of heavy metals in surface water of the Taizi River. Applied Mechanics and Materials, 295-298: 1615 - 1618.

33. Yao, H., Qian, X., Gao, H., Wang, Y. and Xia, B. (2014). Seasonal and spatial variation of heavy metals in two typical Chinese Rivers: Concentrations, environmental risk, and possible sources. International Journal of Environmental Research and Public Health, 11: 11860 - 11878.

34. Dey, S., Das, J. and Manchur, M. A. (2015). Studies on heavy metal pollution of Karnafully River, Chittagong, Bangladesh. Journal of Environmental Science, Toxicology and Food Technology, 9: 79 - 83.

35. Mohiuddin, K. M., Otomo, K., Ogawa, Y. and Shikazono, N. (2012). Seasonal and spatial distribution of trace elements in the water and sediments of the Tsurumi river in Japan. Environmental Monitoring and Assessment, 184: $265-279$.

36. Adamu, C. I., Nganje, T. N. and Edet, A. (2015). Heavy metal contamination and health risk assessment associated with abandoned barite mines in Cross River State: Southeastern Nigeria. Environmental Nanotechnology, Monitoring and Management, 3: 10 - 21.

37. Kumar, R. N., Solanki, R. and Kumar, J. I. N. (2013). Seasonal variation in heavy metal contamination in water and sediments of river Sabarmati and Kharicut canal at Ahmedabad, Gujarat. Environmental Monitoring and Assessment, 185: 359 - 368.

38. Li, S. Y. and Zhang, Q. F. (2010). Risk assessment and seasonal variations of dissolved trace elements and heavy metals in the Upper Han River, China. Journal of Hazardous Materials, 181: 1051 - 1058.

39. Krika, A. and Krika, F. (2017). Evaluation of the status of heavy metal pollution in surface water and sediments of the Nill River (North Eastern Aleria). Pollution, 3(2): 301 - 310.

40. Department of Environment, Government of the People's Republic of Bangladesh (2002). The general overview of pollution status of rivers of Bangladesh, Dhaka, Bangladesh.

41. Department of Environment (1997). The environment conservation rules. Poribesh Bhaban E-16, Agargaon, Shere Bangla Nagar Dhaka 1207, Bangladesh: pp. 179-226.

42. Suresh, G., Sutharsan, P., Ramasamy, V. and Venkatachalapathy, R. (2012). Assessment of spatial distribution and potential ecological risk of the heavy metals in relation to granulometric contents of Veeranam lake sediments, India. Ecotoxicology and Environmental Safety, 84: 117 - 124. 


\section{Haque et al: SEASONAL VARIATION AND ECOLOGICAL RISK ASSESSMENT OF HEAVY METAL CONTAMINATION IN SURFACE WATERS OF THE GANGES RIVER (NORTHWESTERN BANGLADESH)}

43. Li, F. Y., Fan, Z. P., Xiao, P. F., Oh, K., Ma, X. P. and Hou, W. (2009). Contamination, chemical speciation and vertical distribution of heavy metals in soils of an old and large industrial zone in Northeast China. Environmental Geology, 54: 1815 - 1823.

44. Ewa, E. E., Iwara, A. I., Offiong, V. E., Essoka, P. A. and Njar, G. N. (2013). Seasonal variation in heavy metal status of the Calabar River, Cross River State, Nigeria. Journal of Natural Sciences Research, 3(11): 78 - 83.

45. George, P., Joseph, S. and Moses, S.A. (2017). Heavy metal monitoring and health risk assessment of a tropical mountainous river in Kerala, India. International Journal of River Basin Management, 15(4): 475 - 484.

46. Giri, S. and Singh, A.K. (2014). Assessment of surface water quality using heavy metal pollution index in Subarnarekha River, India. Water Quality Exposure and Health, 5: 173 - 182. 